\title{
STRATEGY MAPS PENYELENGGARAAN E-GOVENRMENT PADA BADAN PELAYANAN PERIZINAN DAN PENANAMAN MODAL KOTA BAUBAU
}

\author{
Farid Yusuf Nur Achmad \\ Program Studi Ilmu Pemerintahan, Fakultas Ilmu Sosial dan Ilmu Politik, \\ Universitas Muhammadiyah Buton, Jl. Betoambari No. 36 Baubau. \\ E-mail: faridyusufnurachmadumb@gmail.com
}

\begin{abstract}
Abstrak
Penelitian ini bertujuan untuk mengetahui dan menganalisis pemetaan strategi organisasi pada BP3M Kota Baubau, dengan menggunakan pemodelan Strategy Maps oleh Kaplan dan Norton. Alat analisis Swoot digunakan, untuk mengetahui faktor-faktor internal dan eksternal yang mempengaruhi penerapan teknologi informasi penyelenggaraan $e$-Gvernment. Hasil penelitian menunjukkan bahwa penyelenggaraan strategi BP3M, yaitu (1) Partisipasi pengguna, peningkatan transparansi informasi, kemudahan layanan; (2) Sharing informasi antar SKPD, penyederhanaan prosedur birokrasi. Elemen proses internal diketahui ada dua strategi, yakni (1) Peningkatan infrastruktur pelayanan masyarakat; (2) peningkatan fungsi media portal, stabilitas aplikasi sistem informasi, peningkatan penggunaan software legal. Perspektif Pertumbuhan ada empat strategi, yakni (1) peningkatan kualitas sumber daya manusia; (2) Tata kelola organisasi; (3) e-leadership; (4) research and development software dan hardware. Elemen Keuangan diketahui ada dua, yakni (1) Efisiensi Penggunaan Dana; (2). peningkatan sumber dana lain perlu dilakukan untuk menanggulangi permasalahan dari sudut pengganggaran, salah satunya melalui hibah (grant) atau melalui sumber pendanaan lain. Direkomendasikan bahwa strategy maps yang dilakukan oleh BP3M Kota Baubau dalam penyelenggaraan e-gov, telah menggunakan pemodelan Strategy Maps oleh Kaplan dan Norton.
\end{abstract}

Kata kunci: pemodelan, strategy maps, pelayanan e-gov, teknologi informasi.

\begin{abstract}
This study aims to identify and analyze the mapping of the organization's strategy on BP3M Baubau, using modeling Strategy Maps by Kaplan and Norton. Swoot analysis tool used to determine the internal and external factors that affect the application of information technology implementation of e-Gvernment. The results showed that the implementation of the strategy BP3M, namely (1) User participation, increased transparency of information, ease of service; (2) Sharing information between SKPD, simplification of bureaucratic procedures. Elements of internal processes in mind there are two strategies, namely (1) Improving infrastructure, community services; (2) improving the function of the media portal, the stability of the application of information systems, increased use of legal software. Growth perspective there are four strategies, namely (1) improving the quality of human resources; (2) Organizational governance; (3) e-leadership; (4) research and development of software and hardware. Financial elements are known that have two. (1) Efficiency of Use of Funds; (2) increase other sources of funds needs to be done to tackle the problem from the point of budgeting, one through a grant (grant) or through other funding sources. Recommended strategy maps that were done by BP3M Baubau in the implementation of e-gov, has been using modeling Strategy Maps by Kaplan and Norton.
\end{abstract}

Keywords: Modeling, strategy maps, e-gov services, information technology. 


\section{SANG PENCERAH}

Volume 2, Nomor 2, Agustus 2016, ISSN 2460-5697, Hlm. 9-19

Farid Yusuf Nur Achmad: Strategy Maps Penyelenggaraan ...

\section{Pendahuluan}

Perencanaan strategis organisasi adalah suatu rencana jangka panjang yang bersifat menyeluruh, memberikan rumusan ke mana organisasi akan diarahkan, dan bagaimana sumberdaya dialokasikan untuk mencapai tujuan selama jangka waktu tertentu dalam berbagai kemungkinan keadaan lingkungan. Perencanaan Strategic (Strategic Plans) juga merupakan suatu proses pemilihan tujuan-tujuan organisasi, penentuan strategi, kebijaksanaan, programprogram strategi yang diperlukan untuk tujuan-tujuan tersebut. Terdapat tiga alasan mendasar yang menunjukkan pentingnya perencanaan strategis (1) Perencanaan strategic memberikan kerangka dasar dalam mana semua bentuk-bentuk perencanaan lainnya yang harus diambil; (2) Pemahaman terhadap perencanaan strategic akan mempermudah pemahaman bentuk-bentuk perencaaan lainnya; dan (3) Pemahaman terhadap perencanaan strategic akan mempermudah pemahaman bentuk-bentuk perencaaan lainnya. Secara umum proses perencanaan strategis memuat unsur-unsur (1) perumusan visi dan misi; (2) pengkajian lingkungan eksternal; (3) pengkajian lingkungan internal; (4) perumusan isu-isu strategis; dan (5) penyusunan strategi pengembangan (yang dapat ditambah dengan tujuan dan sasaran).

Untuk mencapai keberhasilan dari proses penataan strategis organisasi dapat dilakukan melalui perencanaan strategis dengan melaksanakan penyusunan dan pengembangan strategi organisasi. Beberapa pendekatan dan teknik analisa strategi dapat digunakan untuk menyusun dan mengembangkan perumusan strategi dalam menghadapi perubahan lingkungan organisasi di dalam suatu proses manajemen strategis. Dinamika perubahan lingkungan organisasi akan membawa dampak yang merugikan maupun yang menguntungkan, baik secara langsung maupun tidak langsung yang berpengaruh pada kelangsungan hidup organisasi. Dengan demikian proses manajemen strategis diharapkan dapat membantu organisasi dalam menghadapi dampak dari dinamika perubahan lingkungannya (David dalam hendrawan, 2005)

Peta strategi atau Strategy Maps adalah alat yang mengartikulasikan strategi organisasi melalui serangkaian hubungan sebab-akibat lintas fungsional. Membangun peta strategi biasanya melibatkan memahami tema kunci strategis dalam empat perspektif umum: keuangan, pelanggan, proses, dan pembelajaran dan pertumbuhan. Keempat perspektif tersebut dikembangkan oleh Kaplan dan Norton pada awal 1990-an sebagai bagian dari metodologi Balanced Scorecard mereka. Teori ini berlaku untuk kedua organisasi sektor swasta dan publik, meskipun titik awal biasanya berbeda. Tujuan strategi adalah kunci dari perubahan masa depan organisasi. Ia mengarahkan pada apa yang hendak dikerjakan diwaktu yang akan datang, arah itu harus jelas dan tegas bagi keseluruhan organisasi. Tujuan strategi merupakan planning umbrella, payung perencanaan (Salusu, 1996). Selanjutnya Untuk dapat melakukan hal tersebut, tujuan strategi harus lebih tajam dari pada misi, namun masih cukup luas untuk dapat mendorong lahirnya kreatifitas dan inovasi bagi semua unit kerja, dengan demikian tujuan strategi merupakan instrumen yang paling kritis dalam menjuruskan semua usaha menuju perubahan yang dikehendaki. (Koteen, 1991).

Beberapa manfaat yang bisa diperoleh dari pemetaan strategi. Titik paling penting adalah fokus pada lintas fungsi organisasi. Masalah organisasi saat ini seringkali terlalu rumit untuk dipecahkan pada fungsi-byfungsi dasar. Peta Strategi memaksa organisasi untuk berpikir tentang bagaimana berbagai fungsi berinteraksi dengan mendukung satu sama lain. Dengan sendirinya peta strategis menjadi alat 


\section{SANG PENCERAH}

Volume 2, Nomor 2, Agustus 2016, ISSN 2460-5697, Hlm. 9-19

\section{Farid Yusuf Nur Achmad: Strategy Maps Penyelenggaraan ...}

komunikasi yang efektif kepada seluruh pelaku dalam organisasi untuk mendukung tujuan yang ingin dicapai, betapa tidak peta strategis memberikan keseragaman langkah yang konsisten dalam menguraikan strategi sehingga sasaran strategis dapat dicapai.

Empat elemen yang direkomendasikan dalam pemodelan Strategy Maps akan mengarahkan pimpinan untuk melihat organisasi dari empat elemen yang saling berhubungan, elemen-elemen tersebut adalah (1) Proses pembelajaran dan pertumbuhan. elemen ini meliputi pelatihan pembentukan sikap para pekerja secara individual dan menumbuhkan sikap budaya organisasi secara korporasi; (2) Proses bisnis internal. Hal ini mengacu pada proses bisnis internal. Berdasarkan elemen ini memungkinkan manajer untuk mengetahui seberapa baik bisnis mereka berjalan, dan apakah produk dan/atau jasa yang ditawarkan sesuai dengan kebutuhan pelanggan atau tidak; (3) Pelanggan. yakni filosofi manajemen terbaru yang menggaris bawahi pentingnya fokus pada pelanggan dan kepuasan mereka dalam kegiatan apapun, dan (4) Keuangan.

Kaplan dan Norton (2004) tidak mengabaikan pentingnya data keuangan. Dengan demikian data keuangan, dana, tepat waktu, dan akurasi akan selalu menjadi prioritas dalam suatu organisasi. Dalam mentranformasikan rencana strategis pemerintah, kedalam sebuah tindakan nyata pemerintah perlu menggunakan alat untuk melakukan interaksi langsung dengan masyarakat sebagai costumer, pengguna akhir dari produk perencanaan strategi tersebut. Salah satu media yang digunakan oleh pemerintah, sebagai wadah dalam melakukan interaksi tersebut adalah electronic government. E-Gov merupakan bentuk dari implementasi penggunaan teknologi informasi bagi pelayanan pemerintah kepada publik. Pengembangan e-gov merupakan upaya untuk mengembangkan pemerintahan yang berbasis elektronik dalam rangka meningkatkan kualitas layanan publik secara efektif dan efisien sesuai dengan prinsip dari New Public Management (NPM). Definisi dari Electronic Government (e-Gov) itu sendiri menurut Bank Dunia (World Bank) adalah penggunaan teknologi informasi (seperti Wide Area Network, Internet dan mobile computing) oleh pemerintah untuk mentransformasikan hubungan dengan masyarakat, dunia bisnis dan pihak yang berkepentingan (http://www.kepripov.go.id diakses pada 9 Maret 2015).

Paradigma pelayanan pemerintah yang bercirikan pelayanan melalui birokrasi yang lamban, prosedur yang berbelit, dan tidak ada kepastian berusaha diatasi melalui penyelenggaraan $e-G o v$ ini. Penyampaian pelayanan kepada publik di dalam paradigma e-Gov tidak lagi dilakukan melalui dokumen-dokumen dan interaksi personal melainkan sudah dilakukan melalui elektronik sehingga tidak ada lagi interaksi personal di dalam pemberian pelayanan. Orientasi efisiensi biaya produksi di dalam pemberian pelayananpun telah bergeser kepada orientasi yang menekankan pada fleksibilitas, pengawasan, dan kepuasan pengguna (customer).

Kota Baubau merupakan salah satu Kota di Indonesia yang telah menerapkan $e$ gov di dalam menjalankan urusan pemerintahannya. Pembangunan e-Gov di Kota Baubau sendiri dimulai sejak tahun 2001. hingga tahun 2005. website resmi pemerintah Kota Baubau dipublikasikan dengan alamat www.baubaukota.go.id di bawah pengelolaan Unit Pembantu Teknis Pembangunan dan Pengembangan Teknologi Informasi UPT-PPTI Kota Baubau sebagai unsur yang bertanggungjawab di dalam pembangunan dan pengembangan $e$ gov di Kota Baubau. Namun dalam implementasinya, e-Gov di Kota Baubau hingga tahun 2014 menghadapi berbagai kendala sehingga belum dapat berjalan 


\section{SANG PENCERAH}

Volume 2, Nomor 2, Agustus 2016, ISSN 2460-5697, Hlm. 9-19

Farid Yusuf Nur Achmad: Strategy Maps Penyelenggaraan ...

secara maksimal. Ketidak siapan pemerintah, mencakup Sumber Daya Manusia/Aparatur, Infrasturktur, Anggaran menjadi faktor utama dari proses penyelenggaraan $e$-Gov di Kota Baubau. Permasalahan ini bisa diselesaikan dengan pemetaan strategi yang baik dalam penyelenggaraannya, pemetaan dimaksud tidak hanya menggambarkannya dalam bentuk bagan namun mewujudkan dalam bentuk aksi nyata dengan menghubungkan empat elemen yang direkomendasikan oleh Kaplan dan Norton dalam beberapa penelitiannya, elemen-elemen tersebut berhubungan secara terus menerus, menjadi sebuah aksi nyata dalam mewujudkan tujuan dari organisasi. Fokus penelitian ini adalah bagaimana Pemetaan Strategi dari penyelenggaraan $e$-Gov pada Badan Pelayanan Perizinan dan Penanaman Modal Kota Baubau, dengan menggunakan pemodelan Strategy Maps yang dirumuskan oleh Kaplan dan Norton pada pencapaian visi organisasi?

Tujuan penelitian ini adalah untuk mengetahui Pemetaan Strategi dari penyelenggaraan e-Gov pada Badan Pelayanan Perizinan dan Penanaman Modal Kota Baubau, dengan menggunakan pemodelan Strategy Maps yang dirumuskan oleh Kaplan dan Norton pada pencapaian visi organisasi.

\section{Metode Penelitian}

Jenis penelitian yang digunakan pada penelitian ini, adalah penelitian Kualitatif eksploratory. Metodologi kualitatif sebagai prosedur penelitian yang menghasilkan data deskriftif berupa kata-kata tertulis atau lisan dari orang-orang dan prilaku penulis". Pada riset kualitatif, eksplorasi permasalahan, identifikasi faktor dan penyusunan teori menjadi ciri-khas utama. (Bodgan dan Taylor dalam Moleong, 2010). Penelitian ini dimulai dari fakta atau fenomena yang tidak dapat dikendalikan oleh penulis dengan menggunakan awalan bagaimana (how), dan mengapa (why). Metode studi kasus tepat digunakan karena penelitian ini banyak melakukan investigasi terhadap penyelenggaraan e-gov terhadap keterkaitan elemen-elemen dari pemodelan strategy maps oleh (Kaplan dan Norton, 2001), sebagaimana telah dijabarkan dalam tujuan penelitian ini.

Penelitian ini difokuskan pada Badan Pelayanan Prizinan dan Penanaman Modal (BP3M) Kota Baubau, Propinsi Sulawesi Tenggara. Serta beberapa Instansi yang memiliki keterkaitan dengan judul penelitian ini. Dengan alasan bahwa Badan Pelayanan Prizinan dan Penanaman Modal (BP3M) adalah SKPD terkait yang memiliki tugas dan tanggung jawab penuh dalam pemberian pelayanan perizinan. Penelitian ini hanya mengamati, menganalisis tentang sejauh mana strategy maps penyelenggaraan e-gov pada BP3M Kota Baubau dalam rangka pelayanan kepada masyarakat dengan menggunakan elemen-elemen dari pemodelan strategy maps oleh Kaplan dan Norton.

1. Analisis Deskriptif Kualitatif ditujukan untuk mendapatkan informasi tentang berbagai kondisi lapang yang bersifat tanggapan dan pandangan terhadap pelaksanaan program perkuatan serta kondisi lingkungan sosial ekonomi dan daerah sample. Hasil analisis kualitatif berupa perbandingan kondisi riil di lapang yang diperoleh dari pendapatpendapat berbagai unsur yang terlibat disesuaikan dengan elemen-elemen yang terkandung pada pemodelan Strategy Maps, oleh Kaplan dan Norton.

(1) Analisis SWOT, Matriks SWOT digunakan untuk menggambarkan peluang dan ancaman dari lingkungan eksternal diantisipasi dengan kekuatan dan kelemahan yang dimiliki dari lingkungan internal. Matriks ini dapat menghasilkan empat kemungkinan alternatif strategi. Masing-masing 


\section{SANG PENCERAH}

Volume 2, Nomor 2, Agustus 2016, ISSN 2460-5697, Hlm. 9-19

Farid Yusuf Nur Achmad: Strategy Maps Penyelenggaraan ...

alternatif strategi itu adalah (1) Strategi SO (Strength-Opportunity) Kekuatan Peluang; (2) Strategy ST (StrengthThreath) Keku-atan Ancaman; (3) Strategy WO (Weakness-Opportunity) Kelemahan Peluang; dan (4) Strategy WT (Weakness-Threat) Kele-mahan Ancaman

\section{Pembahasan}

Pelayanan Perizinan dan Non Perizinan Dalam Rangka Pelayanan Terpadu Satu Pintu Kepada Badan Pelayanan Perizinan dan Penanaman Modal Kota Baubau. Dimana uraian tugas dari masingmasing Dinas Teknis yang terhubungan dengan dengan BP3M dalam penerbitan satu izin belum jelas, masih adanya tumpang tindih tugas, akibatya tidak obtimal pelayanan yang diberikan, sebaiknya seluruh bentuk pelayanan yang sudah dilimpahkan kepada kami sudah harus dilaksanakan, tetapi kenyataannya sampai hari ini dinas teknis tersebut tidak mau melepaskan, tentunya dengan berbagai dalih yang memojokkan BP3M.

Fenomena dilapangan terlihat bahwa dari 53 kewenangan penyelenggaraan perizinan dan 3 nonperizinan, hanya 18 jenis izin yang dikelola oleh BP3M Kota Baubau, 18 jenis izin tersebut berdasarkan hasil survei IKM menyebutkan bahwa 200 responden sebagai target survei, selama 60 hari survei dilakukan, hanya 6 izin/non izin saja yang kemudian direkomendasikan untuk mewakili survei tersebut, ke enam izin/non izin tersebut antara lain (1) Surat izin Tempat Usaha (SITU); (2) Izin Gangguan (HO); (3) Izin Mendirikan Bangunan (IMB); (4) Izin Reklame, Surat Izin Usaha Perdagangan (SIUP); (5) Surat Izin Tempat Usaha (SITU); dan (6) Tanda Daftar Perusahaan (TDP).

\section{Strategi BP3M Kota Baubau}

Strategi BP3M yang merupakan rencana yang menyeluruh dan terpadu mengenai upaya-upaya organisasi yang meliputi penetapan kebijakan, program operasional, dan kegiatan atau aktivitas dengan memperhatikan sumber daya organisasi serta keadaan lingkungan yang dihadapi. Dari pemahaman ini, maka cara mencapai tujuan dan sasaran merupakan faktor terpenting dalam proses perencanaan strategis. Dari strategi tersebut, maka disusun Kebijakan yang berfungsi sebagai pedoman dalam pelaksanaan tindakantindakan tertentu untuk mencapai tujuan dan sasaran organisasi. Implementasi Visi dan Misi Badan Pelayanan Perizinan dan Penanaman Modal Kota Baubau tersebut dilakukan melalui strategi dan kebijakan yang akan dilakukan tahun mendatang secara jelas dipaparkan berikut; Misi, Menata Sistem dan Prosedur Pelayanan yang Mudah, Cepat, Jelas dan Tepat Waktu,

\section{Lingkungan Strategis Penyelenggaran e-gov}

Sebagaimana pemanfaatan e-gov berdasarkan fungsi pemerintahan, maka pengguna e-gov juga dapat dikelompokkan pada enam aspek yaitu (1) Pengguna e-gov Berdasarkan Fungsi Pelayanan; (2) Pengguna $e$-gov Berdasarkan Fungsi Administrasi dan Managemen; (3) Pengguna e-gov Berdasarkan Fungsi Legislas; (4) Pengguna e-gov Berdasarkan Fungsi Pembangunan; (5) Pengguna e-gov Berdasarkan Fungsi Keuangan Daerah; dan (6) Pengguna e-gov Berdasarkan Fungsi Kepegawaian. Berdasarkan hasil Observasi pada obyek penelitian diketahui bahwa pengguna $e$-gov berdasarkan fungsi pelayanan di lingkungan Badan Pelayanan Perizinan dan Penanaman Modal Kota Baubau terdiri atas, Instansi pemerintah, Kecamatan, Desa/Kelurahan, dunia usaha, masyarakat, pers, LSM/Ngo's, ormas. Pengguna $e$-gov. 


\section{SANG PENCERAH}

Volume 2, Nomor 2, Agustus 2016, ISSN 2460-5697, Hlm. 9-19

Farid Yusuf Nur Achmad: Strategy Maps Penyelenggaraan ...

Diketahui juga bahwa pengguna e-gov berdasarkan fungsi Administrasi dan Managemen adalah perangkat daerah Kota Baubau. Selanjutnya, pengguna e-gov berdasarkan fungsi legislasi adalah: DPRD, KPU, Parpol, Pers, masyarakat, LSM dan pengguna e-gov berdasarkan Fungsi Pembangunan di Lingkungan Pemerintah Kota Baubau adalah instansi pemerintah, dunisa usaha, Masyarakat, pers, LSM/Ngo's, ormas. Pengguna e-gov Berdasarkan Fungsi Keuangan Daerah di Lingkungan Pemerintah Kota Baubau adalah instansi pemerintah, DPRD, Masyarakat, pers, LSM/Ngo's, ormas. Pengguna e-gov. Berdasarkan Fungsi Kepegawaian di Lingkungan Pemerintah Kota Baubau adalah instansi pemerintah, masyarakat (pelamar PNS).

Sistem e-gov tidak saja menyangkut infrastruktur jaringan sebagai sarana komunikasi data dan aksesibilitas informasi tetapi juga menyangkut infrastruktur yang menyangkut struktur data dan proses sistem informasi sebagai landasan bagi aplikasi sistem informasi pemerintah. Pemasalahan jaringan infrastruktur yang dihadapi tidak semata-mata menyangkut masalah teknis fisik semata, tetapi juga mencakup masalah kepemimpinan, sumberdaya manusia, regulasi dan faktor-faktor prosedural seperti keamanan, kewenangan pengelolaan data dan cetak biru arsitektur sistem yang belum dimiliki oleh setiap instansi maupun lembaga pemerintahan. Dengan demikian, langkah berikutnya adalah mengidentifikasikan faktor internal dan faktor eksternal yang berpengaruh terhadap proses penyelenggaraan e-gov di BP3M Kota Baubau.

Salah satu tugas pokok BP3M adalah memberikan pelayanan kepada masyarakat Kota Baubau tanpa batas, keterbukaan informasi, dan efisiensi waktu, menjadikan BP3M Kota Baubau sebagai induk pembangunan dan pengendalian sistem pelayanan berbasis digital. Pembangunan infrastruktur jaringan teknologi informasi dan komunikasi (TIK) BP3M Kota Baubau yang koordinasinya tidak terlepas dari kontrol Unit Pembantu Teknis Pembangunan dan Pengembangan Teknologi Informasi UPT-PPTI Kota Baubau sebagai pengendali yang menghubungkan setiap SKPD serta komitmen pimpinan dan kerjasama dengan Departemen Komunikasi dan Informasi RI, yang diawali pada bulan Mei 2008 lalu ketika cara pandang terhadap TIK telah bergeser dari semua menggunakan mesin ketik manual menuju komputer dan dari komputer-komputer yang berdiri sendiri (stay alone) menjadi sebuah jaringan

Dari hasil wawancara yang dilakukan dipangan pada dasaranya fenomena yang menjadi permasalahan dalam penyelenggaraan model pelayanan berbasis Teknologi Digital tersebut diatas konstruksi pembangunan sarana dan prasarana pelayanan publik dibuat dan disesuaikan dengan tingkat pemahaman para pengguna layanan dalam hal ini publik, sehingga terkesan model pelayanan yang terbilang baru ini lebih mudah dipahami oleh pengguna (user). Sebagai satuan kerja perangkat daerah Kota Baubau yang mengalami peningkatan status, maka terjadi penambahan pegawai walaupun sekarang masih dirasakan kurang. Hal ini disebabkan karena penambahan pegawai hanya diperuntukan untuk mengisi jabatan struktural seperti jabatan Sekretaris, Kepala Bidang dan Kepala Seksi.

Berdasarkan data Analisis Jabatan (ANJAB) BP3M Kota Baubau tahun 2015, dijelaskan bahwa, jumlah personil pada BP3M Kota Baubau sebanyak 32 orang yang masing-masing terdiri dari 22 orang PNS dan 10 orang Pegawai Tidak Tetap. Sedangkan, jumlah pejabat struktural yang terisi sebanyak 11 jabatan. Adapun jabatan yang belum terisi adalah Jabatan eselon III.b (Kepala Bidang Penanaman Modal) dan eselon IV.a pada Bidang Perizinan (Kepala Seksi Pengolahan) dan Bidang Penanaman 
Farid Yusuf Nur Achmad: Strategy Maps Penyelenggaraan ...

Modal (Kepala Seksi Pengendalian dan Penanaman Modal). Selanjutnya, untuk pendanaan indikatif semuanya bersumber dari Anggaran Pendapatan dan Belanja Daerah (APBD) Kota Baubau Tahun 2015. Berdasarkan program strategis Pemerintah Kota Baubau dan untuk mendukung pencapaian visi dan misi serta pelaksanaan TUPOKSI Badan Pelayanan Perizinan dan Penanaman Modal Kota Baubau menetapkan Program dan Kegiatan yang disesuaikan dengan Peraturan Menteri Dalam Negeri Nomor 13 Tahun 2006 tentang Pedoman Pengelolaan Keuangan Daerah.

\section{Kondisi Eksisting Implementasi E-gov}

\section{1) Kondisi Infrastruktur E-gov}

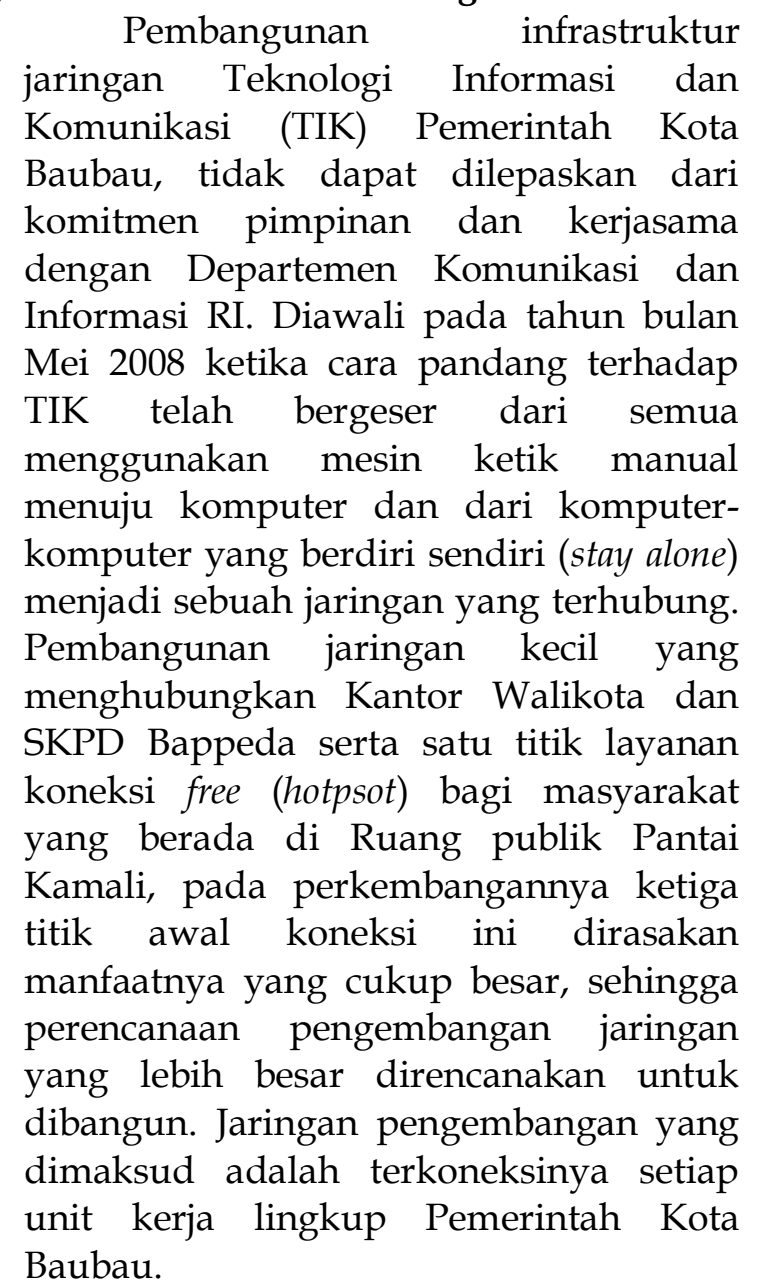

Merupakan keuntungan tersendiri bagi Pemerintah Kota Baubau yang memiliki pusat pemerintahan secara topologi terletak pada daerah ketinggian, dengan demikian pembangunan jaringan menjadi relatif lebih mudah dan murah. Untuk menghubungkan kantor satu dengan lainnya pada lingkup Pemerintah Kota Baubau dilakukan dengan sambungan radio nirkabel (wireless). Koneksi antar SKPD yang berada di luar kawasan Kantor Walikota dibangun dengan fasilitas tower triangle 25 meter dan dihubungkan dengan radio wireless. Pembiayaan untuk membangun jaringan ini menjadi relatif murah karena disamping kawasan tidak terlalu luas, juga karena dilakukan dengan sistem swakelola. Hal ini didukung oleh keinginan besar untuk memberdayakan potensi sumber daya lokal agar bisa melakukan alih teknologi sehingga lebih mandiri.

Pembangunan jaringan dalam arti perluasan jaringan sampai kepada level staf terus dilakukan sesuai dengan permintaan atas pertimbangan kebutuhan SKPD. Dengan kemungkinan perluasan jaringan sampai pada level staf diharapkan penguasaan komputer dan bekerja dengan komputer dengan fasilitas jaringan akan semakin tinggi, sekaligus dapat memenuhi kebutuhan dan harapan masyarakat akan kualitas pelayanan.

\section{2) Kondisi Eksisting Pengguna/Users E- goverment Kota Baubau}

Masyarakat Kota Baubau adalah masyarakat yang dinamis, sikap dan pandangan lebih penting daripada proses penerimaan suatu informasi bernuansa teknologi. Individu di dalam suatu komunitas masyarakat akan bersikap atau bereaksi terhadap suatu situasi dan kondisi sosial tergantung segi kualitas materi informasi teknologi. Sehingga strategi komunikasi teknologi mempunyai ruang lingkup lebih luas dan mencakup aspek interaksi antara masyarakat dengan teknologi. Studi 


\section{SANG PENCERAH}

Volume 2, Nomor 2, Agustus 2016, ISSN 2460-5697, Hlm. 9-19

Farid Yusuf Nur Achmad: Strategy Maps Penyelenggaraan ...

mengenai pendekatan dan indikator pemahaman masyarakat tentang teknologi umumnya terdiri tiga unsur pokok yang saling berkaitan antara satu sama lain: ketertarikan, pengetahuan, dan perilaku.

Berdasarkan data lokal area network conektion yang diperoleh dari http://www.profile_egovbaubaukota.go. id UPT-PPTI Kota Baubau tercatat bahwa fasilitas teknologi yang telah dibangun oleh Pemerintah Kota Baubau saat ini $30 \%$ masyarakat telah menggunakan. Data ini diperoleh berdasarkan penggunaan koneksi internet free http://www.uptppti_baubaukota.go.id yang ada di Kota Baubau. Dengan pengunaan fasilitas media surat warga yang dapat diakses online saat ini 5\% jumlahnya.

\section{Strategi Penyelenggaraan e-gov BP3M Kota Baubau}

Strategi penyelenggaraan e-gov BP3M Kota Baubau merupkan operasionalisasi dari Visi dan Misi e-gov Kota Baubau yang telah dirumuskan sebelumnya. Kesesuaian antara strategi makro pemerintah dengan strategi sektoral ini relevan dengan pernyataan Fred R. David, bahwa Strategi adalah cara untuk mencapai tujuan-tujuan jangka panjang Organisasi, (David, 2004) untuk itu Strategi Penyelenggaraan e-gov BP3M Kota Baubau terdiri dari sembilan strategi sebagaimana diuraikan berikut ini. Strategi Pertama, penyediaan layanan informasi yang mampu mendukung terwujudnya masyarakat yang kompetitif serta menarik investasi ke Kota Baubau. Strategi ini dijalankan dengan tiga tujuan, yaitu: (1). partisipasi pengguna, (2). peningkatan transparansi informasi, (3). kemudahan layanan.

Strategi kedua, koordinasi layanan yang tertata dan terorganisasi. Strategi ini dijalankan dengan dua tujuan, yaitu; (1). Sharing informasi antar SKPD, (2).
Penyederhanaan prosedur birokrasi. Strategi ketiga, Pembangunan infrastruktur dan akses jaringan komunikasi data yang memadai. Strategi ini dijalankan dengan tujuan, peningkatan infrastruktur. Strategi keempat, Pengembangan perangkat-perangkat lunak. strategi ini dijalankan dengan tiga tujuan, meliputi;(1). Peningkatan fungsi media portal, (2). Stabilitas aplikasi sistem informasi, (3). Peningkatan penggunaan software legal.

Strategi kelima, Pemeliharaan dan pengujian perangkat lunak dan keras/jaringan. Program yang dilakukan untuk mencapai strategi ini dengan melakukan Riset and Development perangkat lunak dan perangkat keras/jaringan. Strategi keenam, Pembuatan aturan perundangan dan kebijakan yang diperlakukan untuk mendukung $e$ governemnt. Strategi ini dijalankan dengan tujuan memperkuat komitmen pemerintah Kota Baubau dalam mendukung dan menerapkan konsep e-gov. Strategi ketujuh, Berupa pengembangan SDM untuk mengelola $e$-gov. Strategi yang direncanakan untuk mendukung strategi ini adalah peningkatan kualitas SDM. Peningkatan kualitas SDM tidak hanya dalam melakukang pendidikan ataupun pelatihan akan tetapi dengan melakukan rekruitmen anggota yang mempunya kualifikasi dan kualitas yang memumpuni merupakan hal yang sangat mendorong peningkatan kualitas kinerja.

Strategi kedelapan, Pengembangan organisasi dan tata kerja yang mendukung $e$ gov. Strategi yang dirancang untuk mendukung adalah tata kelola organisasi, pembentukan satu unit kerja khusus dalam melaksanakan fungsi operasional teknis. Strategi kesembilan, Pengalokasian anggaran yang terencana, untuk mendukung strategi terakhir ini dilakukan dengan dua pendekatan, yaitu; (1). Efisiensi penggunaan dana, efisiensi penggunaan dana dimaksud adalah bagaimana 


\section{SANG PENCERAH}

Volume 2, Nomor 2, Agustus 2016, ISSN 2460-5697, Hlm. 9-19

\section{Farid Yusuf Nur Achmad: Strategy Maps Penyelenggaraan ...}

melakukan alokasi dana dengan tepat dan sesuai dengan kebutuhan perencanaan. (2) Peningkatan sumber dana lain, peningkatan sumber dana lain adalah peningkatan dana yang diperoleh melalui kerjasama dengan pihak luar untuk mendukung dan lebih memaksimalkan pencapaian

\section{Faktor Internal Penyelenggaraan E-gov}

Kondisi Internal yang meliputi kekuatan (Strengths) dan kelemahan (Weaknesses). Di sisi kekuatan terdapat empat kondisi, antara lain (1) Partisipasi masyarakat dan kalangan bisnis yang besar, Animo masyarakat Kota Baubau untuk meningkatkan kemampuan dalam penguasaan teknologi informasi terlihat meningkat dari waktu ke waktu; (2) Prosedur birokrasi yang cepat dan mudah. Dalam memberikan pelayanan kepada masyarakat, aparatur Pemerintah Kota Baubau terus berbenah dengan melakukan pemotongan birokrasi yang berbelit dan membutuhkan waktu yang lama, saat ini beberapa titik layanan telah dapat dijumpai bentuk layanan yang cepat dan mudah, seperti proses perijinan online yang telah ada; (3) Jalur koneksi dalam jumlah yang besar dan cepat. Dengan pengembangan jumlah titik layanan koneksi internet dan penerapan beberapa aplikasi yang bersifat online 24 jam dipandang perlu untuk meningkatkan kecepatan atau besar lebar pita yang digunakan untuk akses koneksi internet; (4) Pimpinan memiliki e-leadership ditunjang dengan pemahaman konsep pengembangan e-gov secara makro memberikan ruang bagi penerapan dan pengembangan $e$-gov.

Dari sisi kelemahan (weakness) diidentifikasi empat kondisi, yakni (1) Kemampuan SDM yang menguasai dan menggunakan teknologi informasi masih rendah dan penyebaran belum merata. Secara umum kemampuan sumber daya aparatur pemerintah dalam penguasaan teknologi informasi masih rendah hanya beberapa persen yang dapat menguasai dan persebaran nya tidak merata, hal ini menjadi perhatian khusus untuk dapat meningkatkan kemampuan dari aparatur pemerintah. Dari masyarakat sendiri kondisinya tidak begitu berbeda, akan tetapi kamauan untuk meningkatkan kemampuan teknologi informasi tak diragukan; (2) Pengelolaan Tim Informasi Teknologi masih terpusat pada satu titik. Dalam pengelolaan tugas dan maintenance Tim Informasi Teknologi yang ada di Pemerintah Kota Baubau masih terpusat pada satu titik yaitu di kantor Sekretariat Daerah Kota Baubau pada UPT-PPTI. Hal ini menjadi kurang optimal karena dari pesebaran titik pelayanan bertempat pada daerah yang cukup berjauhan, kurang cepat dalam penanganan permasalahan yang ada akan menimbulkan ketidak nyamanan dalam melakukan pelayanan. Kondisi ideal Tim Informasi Teknologi harus pula berada pada titik-titik layanan di setiap SKPD, sehingga dapat dengan sigap dan cepat dalam melakukan pemantauan serta penanganan masalah yang timbul; (3) Rendahnya dana pengalokasian pengembangan teknologi Informasi. Rendahnya dana yang dialokasikan dan atau terhentinya alokasi penganggaran dalam pengembangan teknologi informasi di Pemerintah Kota Baubau menjadi sebab kurangnya akselarasi dalam pembangunan e-gov; (4) Sebahagian besar perangkat lunak adalah ilegal. Data dari Kementrian Depkominfo pada bulan juni 2014 melalui http://www.depkominfori.gm.im perangkat lunak ilegal atau bajakan berkisar pada angka $82 \%$ di indonesia. Jumlah ini mengindikasikan tingginya penggunaan perangkat lunak ilegal yang disebabkan masih rendahnya pendapatan masyarakat untuk menggunakan perangkat lunak yang berlisensi. Kondisi nasional kurang lebih sama yang ada di Kota Baubau, baik di lingkungan aparatur maupun dilingkungan masyarakat. Lingkup aplikasi yang digunakan pada network operation center 


\section{SANG PENCERAH}

Volume 2, Nomor 2, Agustus 2016, ISSN 2460-5697, Hlm. 9-19

Farid Yusuf Nur Achmad: Strategy Maps Penyelenggaraan ...

(NOC) di Pemerintah Kota Baubau seluruh aplikasi menggunakan perangkat lunak yang bersifat open source. Open source adalah sistem pengembangan yang bekerja sama dengan memanfaatkan kode sumber (sourcecode) yang tersebar dan tersedia bebas.

\section{Faktor Ekternal Penyelenggaraan E-gov}

Kondisi ekternal yang meliputi peluang (Opportunities) dan tantangan (Threaths). Di sisi peluang diidentifikasi dua kondisi, antara lain (1) Kemudahan akses terhadap layanan yang dapat mengefektifkan pelayanan kepada masyarakat. Akses koneksi internet merupakan model yang dapat digunakan dalam memberikan pelayanan yang cepat, mudah, dan nyaman. Dengan memberikan pelayanan masyarakat secara online berarti mendidik masyarakat untuk lebih mengenal teknologi informasi; (2) Ketersediaan Infrastruktur akses, infrastruktur komunikasi, infrastruktur koneksi, bagi aparatur dan masyarakat. Infrastruktur merupakan media data dan suara dapat dilewatkan, dengan kekuatan infrastruktur baik akses, komunikasi dan koneksi maka menjadi kemudahan untuk menerapkan aplikasi yang bersifat local area ataupun online.
Dari sisi tantangan (Threat), diidentifikasi empat kondisi, antara lain (1) Perkembangan teknologi informasi yang sangat cepat Perkembangan berlangsung sangat cepat, sebuah teknologi yang dikatakan terbaru dan terbaik pada bulan ini belum tentu berada pada posisi yang sama untuk dua atau tiga bulan ke depan. Konsumen teknologi pun saat ini semakin beragam, tidak hanya pada kalangan pebisnis, tetapi juga sudah mulai menjalar ke berbagai segmen masyarakat. Sangat mudah saat ini kita temui para pelajar bahkan pelajar sekolah dasar sudah sangat familiar dengan teknologi; (2) Masyarakat menginginkan pelayanan yang cepat, tepat dan terpadu, serta ketersediaan informasi yang akurat. Tuntutan akan peningkatan layanan dan kualitas layanan menuntut Pemeritah Daerah Kota Baubau untuk berbenah dan konsisten dalam penerapan serta pengembangan teknologi informasi. Membutuhkan waktu dalam pengembangan layanan sehinggak layanan yang cepat, tepat dan terpadu dapat diterapkan; (3) Dinamika masyarakat yang menuntut terciptanya Good Governance Meningkatkan kesadaran masyarakat akan terciptanya pemerintahan yang baik, baik dalam arti dalam penyelenggaraan maupun dari peningkatan keterbukaan dalam pengelolaan informasi dan keuangan. Pemerintah Kota Baubau dalam usianya yang ke sembilan sebagai daerah otonom, secara berkesinambungan membenahi tingkat pelayanan masyakat menuju masyarakat yang sejahtera; dan (4) Pentingnya penelitian dan pengujian bagi pengembanganan layanan Memberikan layanan yang prima kepada masyarakat dituntut performas sistem yang handal dan dapat bekerja dengan baik. Sistem yang terbangun tentu tidak $100 \%$ berjalan sempurna, dibutuhkan penelitian, pengujian serta monitoring terhadap layanan yang ada.

\section{Simpulan}

Simpulan penelitian ini bahwa penyelenggaraan e-gov pada BP3M Kota Baubau belum terlaksana dengan maksimal disebabkan beberapa faktor antara lain; Sumber Daya Manusia/Aparatur yang belum medai, Keterbatasan Infrastruktur Pendukung, tidak berfungsinya situs resmi BP3M yang telah ada sangat mempengaruhi proses eksistensi penyelenggaraan model pelayanan berbasis Teknologi Digital, Rendahnya kontrol/evaluasi dari penyelenggara pemerintahan, masih adanya ego sektoral yang timbul antara sesama SKPD dalam pengambilan kebijakan penyelenggaraan perizinan, serta keterbatasan anggaran dalam rangka pengembangan model pelayanan perizinan berbasis TIK, dapat menghambat 


\section{SANG PENCERAH}

Volume 2, Nomor 2, Agustus 2016, ISSN 2460-5697, Hlm. 9-19

\section{Farid Yusuf Nur Achmad: Strategy Maps Penyelenggaraan ...}

penyelenggaraannya e-gov; Dalam Kaitannya dengan strategi penyelenggaraan e-gov BP3M Kota baubau, pada dasarnya telah menggunakan elemen-elemen dalam pemodelan Strategy Maps oleh Kaplan dan Norton, meskipun hasil akhir yang direkomendasikan oleh Kaplan, secara sederhana adalah terkoneksinya antara seluruh elemen dalam pemodelan secara simultan, sehingga tidak terkesan tumpang tindih (over leping), masih belum mengarah pada maksud dan tujuan akhir dalam pemodelan oleh Kaplan dan Norton, ego sektoral seperti yang dijelaskan pada point pertama menjadi pemicunya.

\section{Daftar Pustaka}

Bank Dunia. 2002. E-Goverment: A Definition of E-gov.

http://www.worldbank.org/publicsector Legov/definition.htm, (diakses Februari 2014).

Kaplan, Norton. 2001. The Strategy Focused Organization, How Balanced Scorecard Companies Thrive in The New Business Environment, HarvardBusiness School Press, Boston, Massachusetts, USA.

Kaplan, Robert S., and David P. Norton. 2004. Strategy Maps Converting Intangible asstes into Tangible Outcomes. Boston, Massachuttes: Harvard Bussiness School Press.

Koteen, Jack. 1991. Strategic Management in Public and Nonprofit Organization. Praeger Publisher, New York.

Moleong, J. Lexy. 2010. Metode Penelitian Kualitatif, Edisi Revisi. Remaja Rosdakarya: Bandung.
Salusu. 1996. Pengambilan Keputusan Stratejik, Untuk Organisasi Publik dan Organisasi Nonprofit. Cetakan Pertama, 1996. Cetakan Kedua, 1998. Cetakan Ketiga, 2000. Jakarta: Gramedia Widiasarana Indonesia. 